\title{
MERGER MERUPAKAN TANTANGAN ATAU PELUANG BAGI PEREKONOMIAN INDONESIA
}

\author{
Indriatmini Noegroho \\ Sekolah Tinggi Ilmu Ekonomi "Urip Sumoharjo" Surabaya
}

\begin{abstract}
ABSTRAK
Merger sebagai salah satu alternatif untuk mempertahankan suatu perusahaan yang merupakan efisiensi yang bersifat strategik demi kelangsungan hidup suatu perusahaan. Didalam persaingan bebas yang mencakup banyak pesaing, maka diperlukan suatu tatanan yang lebih menyelamatkan suatu perusahaan. Dalam dunia perbankan juga mengalami banyak sekali kondisi bank yang tidak sehat. Dalam rangka mempertahankan sistem perbankan sebagai lembaga keuangan, maka diperlukan merger sebagai penyelamat untuk dunia perbankan. Dengan adanya banyaknya merger bank, diharapak kondisi perbankan di Indonesia lebih sehat. Dengan melakukan merger bank maka keuntungan yang diperoleh semakin besar dan assets bank bertambah. Ini menunjukan bahwa merger sangat berpeluang bagi perekonomian di Indonesia.
\end{abstract}

Kata kunci: Merger

\section{PENDAHULUAN}

\subsection{Latar Belakang}

Krisis perekonomian yang terjadi di wilayah Asia Timur dan Asia Tenggara di tahun sekitas tahun 1997 1998 membawa pengaruh yang bersifat negatif pada dunia Lembaga Keuangan Bank di Indonesia. Bank-bank di Indonesia mengalami krisis kesulitan keuangan sehingga akhirnya bank-bank terlikuidasi. Dampak lain pun terlihat dengan banyaknya bank-bank yang tidak sehat yang harus dilikuidasi karena sudah tidak bisa diselamatkan kembali.
Salah satu cara menangani dampak-dampak krisis yang dialami perbankan adalah dengan dilakukan kebijakan strategi merger dan akuisisi. Strategi ini dinilai dapat menyelamatkan bank-bank yang nyaris terlikuidasi dan membangun kembali ke keadaan yang stabil.

Merger dan akuisisi berkembang di era 1970-an sebagai salah satu kebijakan untuk menangani krisis perekonomian dunia yang didorong oleh faktor-faktor seperti: berstunya sistem perekonomian regional dan perekonomian dunia, adanya ekspansi perusahaan-perusahaan $\mathrm{MNC}$ di 
berbagai negara, serta berbagai terobosan teknologi informasi dan telekomunikasi setelah tahun 1980 yang memudahkan proses alih informasi dan kapital.

Merger dan akuisisi tidak hanya muncul di perbankan negara-negara berkembang atau yang sedang mengalami krisis tetapi juga bermunculan di negara-negara maju seperti di Amerika Serikat, Jerman maupun Jepang dengan tujuan ingin memperoleh keuntungan. Di Indonesia, merger diberlakukan demi diharapkan membentuk daya saing yang kuat dan mampu menggerakkan perekonomian nasional.

Dari 101 bank di Indonesia yang melakukan merger dan akuisisi, 71 bank dilikuidasi dan hanya 30 bank yang masih beroperasi dan bertahan hingga tahun 1998. Di tahun 2001, sebanyak 18 bank dilikuidasi dan selebihnya 12 bank masih beroperasi.

Setelah krisis moneter di Indonesia, hasil dari pelaksanaan merger empat bank menghasilkan Bank Mandiri (2002) dengan aset Rp. 248.884 triliun. Lalu sembilan bank melakukan merger menghasilkan Bank Danamon dengan aset Rp. 54.297 triliun kemudian hasil merger dari lima bank menghasilkan
Bank Permata dengan aset Rp. 32.636 triliun, dan bank-bank lainnya.

Strategi ini digunakan oleh perbankan sebagai keputusan dan langkah strategis yang digunakan untuk memperbaiki kesehatan bank sehingga diharapkan bank dapat bekerja secara efisien dan memperbaiki kepercayaan masyarakat terhadap bank serta mampu menghasilkan keuntungan yang optimal.

Namun, beberapa peneliti menilai adanya kondisi yang seharusnya tidak terjadi dalam merger perbankan justru terjadi. Adanya penurunan laba, simpanan pihak ketiga dan tingginya jumlah kredit yang disalurkan.

Tidak mudah melakukan merger dan akuisisi, karena tidak saja berkaitan dengan masalah bisnis dan keuangan, tetapi juga menyangkut masalah hukum, perpajakan, akuntansi, perijinan, manajemen, tenaga kerja bahkan kultur usaha dari perusahaan-perusahaan yang akan melakukan merger dan akuisisi.

\subsection{Tujuan}

Tujuan makalah ini untuk mengetahui bagaimana perkembangan merger dan akuisisi yang terjadi pada Lembaga Keuangan Bank di Indonesia serta pengaruh baik dampak positif 
maupun dampak negatif atas proses merger tersebut.

\subsection{Kegunaan}

1. Mempelajari perkembangan merger perbankan Indonesia serta peraturan-peraturannya.

2. Mengetahui proses serta tujuan dilakukannya merger .

3. Mengetahui dampak langsung dari pelaksanaan merger pada bank nasional.

\subsection{Rumusan Masalah}

Berdasarkan latar belakang telah diketahui bahwa merger pada perbankan nasional di Indonesia ternyata masih belum cukup sukses di beberapa bank dan masih sulit diterapkan karena prosesnya yang sulit dan menyangkut masalah di berbagai bidang, terkait di bidang bisnis dan juga di bidang hukum, manajemen, pajak, tenaga kerja, dan juga kultur usaha.

Dari kesimpulan diatas, dapat ditarik suatu masalah "apa yang menyebabkan terlaksananya merger pada perbankan Indonesia?”.

\section{TINJAUAN PUSTAKA}

Istilah "merger" berasal dari kata kerja "merge" yang berarti" menggabungkan atau memfungsikan" (Jhon M.E. \& Hassan S, 1990; 378). Merger adalah penggabungan dua perusahaan atau lebih guna membentuk satu perusahaan.

Menurut Smith (1996), tujuan merger bank dimaksudkan untuk mengurangi biaya tenaga kerja, biaya overhead dan mengombinasikan antara efisiensi yang telah dicapai oleh partner merger, dan mengurangi jumlah cabang yang tingkat operasionalnya Overlapping antara satu cabang dengan cabang lain. Merger dan akuisisi digunakan sebagai upaya restuksturisasi dan rekapitalisasi perbankan yang belum memiliki kinerjayang ideal.

Menurut Damodaran (2001), suatu perusahaan dapat diakuisisi perusahaan dengan beberapa cara, yaitu: merger (begabunganya sebuah perusahaan dengan perusahaan lain), konsolidasi (perusahaan baru yang tercipta setelah prosesmerger), tender over (sebuah perusahaan membeli saham yang beredar di perusahaan lain tanpa persetujuan manajemen targer firm), dan acquisistion of assets (sebuah perusahaan membeli aset perusahaan lain melalui persetujuan pemegang saham target firm).

Beberapa macam merger yaitu, merger vertikal, merger horizontal, dan 
merger konglomerat. Merger vertikal adalah perusahaan-perusahaan yang digabung dan beroperasi pada tingkatan berbeda dalam produksi dan pemasaran. Namun, bertujuan untuk meningkatkan distribusi. Sedangkan yang dimaksud merger horizontol ialah perusahaanperusahaan yang digabung karena ingin melakukan diversifikasi, meningkatkan basis pelanggan, mengurangi biaya, atau menawarkan perluasan produk. Serta yang terakhir ialah merger konglomerat bertujuan untuk memacu pendapatan penjualan.

\section{HASIL PENELITIAN DAN PEMBAHASAN}

\subsection{Perkembangan Strategi Merger dan Akuisisi Bank Nasional di Indonesia}

\subsubsection{Merger}

Sistem Merger nampaknya menguntungkan bagi perbankan karena memberikan efisiensi yang cukup menjanjikan bagi eksistensi bank tersebut. Namun dampak dari likuidasi Bank, Merger adalah pengurangan biaya tenaga kerja dimana akibat likuidasi jumlah kemiskinan dan pengangguran meningkat tajam. Dari data Bappenas, tercatat kemiskinan di akhir tahun 1997 meningkat pesat ketimbang awal tahun.
Nampaknya ekonomi Indonesia telah hancur total dari akar hingga ke pucuk daun, karena tidak hanya menyerang masyarakat namun juga perbankan yang saat itu tumbuh sangat baik (Mengingat pertumbuhan ekonomi Indonesia sebelum krisis cukup tinggi bahkan mendapat julukan "Macan Baru Asia").

Penyebab banyak terjadinya merger perbankan pada Krisis Moneter 1997 ialah akibat kebijakan untuk penggajian pejabat pemerintah di Indonesia dengan menggunakan Dollar. Pada saat itu, akibat ulah spekulan valuta asing yang memborong Dollar Amerika lalu menjualnya dengan harga tinggi, harga Dollar secara tragis naik dan saat ditukar ke dalam Rupiah yang terjadi adalah Inflasi.

Banyak Bank di Indonesia menerima imbas dari hal tersebut. Inflasi ini membuat banyak perbankan di Indonesia terancam gulung tikar. Oleh karena itu sampai tahun 1998 dari 101 bank yang melakukan merger dan akuisisi hanya tersisa 30 Bank (71 Bank dilikuidasi) dan kemudian hanya tersisa 12 Bank (InfoBank 2001).

Peningkatan modal bank merupakan salah satu upaya memperkuat sistem perbankan. Permodalan yang kuat pada bank sebagai regulator dalam 
menciptakan bank yang sehat dan aman.Modal bank-bank di Indonesia tergolong rendah jika dibandingkan dengan modal bank di negara tetangga padahal bank dikenal sebagai usaha padat modal dan berisiko tinggi. Ratarata modal inti bank umum di Indonesia adalah Rp.1.347,4 milyar.

Dengan kewajiban untuk meningkatkan modal tersebut diharapkan akan terjadi merger dan akuisisi sehingga struktur kepemilikan bank menjadi lebih sehat. BI mengeluarkan ketentuan yang dikenal dengan kebijakan Kepemilikan Tunggal Pada Perbankan Nasional atau populer dengan single presence policy (SPP). Tujuannya adalah untuk mendorong konsolidasi perbankan dan mendukung efektivitas pengawasan bank.

\subsubsection{Beberapa Contoh Kasus}

\section{A. Merger Bank Century}

Tahun 1998 dari 101 bank yang melakukan merger dan akuisisi hanya tersisa 30 Bank (71 Bank dilikuidasi) dan kemudian hanya tersisa 12 Bank (InfoBank 2001). Di tahun 2004 Century merupakan satu-satunya Bank yang melakukan merger dalam program yang dicanangkan Bank Indonesia yaitu API (Arsitektur Perbankan Indonesia). Hal itu karena Century International merupakan merger dari perbankan yang dimiliki satu orang (bank CIC, Pikko, Danpac).

Adapun kondisi kinerja keuangan bank sebelum dan setelah merger menjadi Bank Century dapat diteliti dengan menggunakan Capital Adequasi Ratio atau rasio permodalan (CAR), CAR pada Bank Pikko, CIC, dan Danpac setelah dilakukan merger menjadi Bank Century mengalami penurunan yaitu pada tahun 2004 dan 2005 sebesar 8,76\% dan 8,36\%, hal ini dikarenakan peningkatan jumlah modal tidak berimbang dengan peningkatan ATMR (Aktiva Tertimbang Menurut Resiko), dimana peningkatan ATMR lebih tinggi daripada peningkatan jumlah modal. Kualitas aktiva produktif pada Bank Century mengalami peningkatan daripada ketiga bank (Bank Pikko, Bank CIC dan Bank Danpac) sebelum dilakukan merger yaitu pada tahun 2004 sebesar $1,52 \%$.

Namun pada tahun 2005 mengalami penurunan sebesar $-0,74 \%$, hal ini disebabkan karena peningkatan beban bunga yang harus ditanggung lebih besar daripada peningkatan pendapatan bunga sehingga pendapatan bunga bersihnya mengalami penurunan 
dan menunjukkan angka negative (Laporan Kemajuan Pemeriksaan Investigasi atas Kasus Bank Century, 2009 )

\section{B. Merger Bank Danamon}

Bank Danamon merupakan hasil pengambil alihan dibawah Badan Penyehatan Perbankan Nasional (BPPN) dari delapan bank, yaitu PT. Bank Tamara Tbk, PT. Bank Tiara Asia Tbk, PT. Bank Rama Tbk, PT JayaBank International, PT. Bank Risyad Salim International, PT. Bank Duta Tbk., PT. Bank Pos Nusantara, dan PT. Bank Nusa Nasional.

Dari ke-8 bank yang bergabung hanya Bank Tamara yang mendapatkan laba sedangkan bank lainnya menderita kerugian dimana biaya yang dikeluarkan dan kerugian yang diderita hampir sebanding besarnya. Dua tahun sebelum merger dari 8 bank yang bergabung hanya Bank Tamara yang mendapatkan laba. Laba yang diperoleh saat itu adalah 2,844,232 (jutaan Rp).

Satu tahun setelah merger Bank Danamon mendapatkan laba sebesar 754,878 (jutaan Rp). Keadaan ini terlihat membaik setelah beberapa bank mengalami kerugian sebelum melakukan merger.

\section{Merger Bank Permata}

Bank permata merupakan hasil merger dari 5 bank yaitu PT. Bank Bali Tbk, PT. Universal Tbk., PT. Prima Express, PT. Arta Media Bank dan PT. Patriot. Nama Bank Permata resmi digunakan pada 18 Oktober 2002 dibawah PP No. 28/2000. Gabungan bank tersebut memiliki kelebihan 320-an kantor cabang, 456 ATM bersama, mempunyai customer base 1,3 juta nasabah dengan produk baru dan bervariasi.

Dua tahun sebelum merger Bank Prima Ekspress memperoleh laba sekitar 7,818 (jutaan Rp), sedangkan bank lainnya menderita kerugian yang cukup besar. Setahun sebelum bergabung terlihat kondisi perubahan bahwa laba dihasilkan oleh Bank Bali dengan 136,975 (jutaan Rp) dan bank lainnya rugi. Cukup besar kerugian yang dicapai Bank Universal sebesar $-1,328,524$ (jutaan Rp).

Satu tahun setelah merger Bank Permata mendapatkan laba sebesar 542,504 (jutaan Rp). Keuntungan yang didapatkan dalam merger bank memang baik, tetapi dari data yang diperoleh dapat diasumsikan bahwa bank hasil merger belum menyalurkan kredit 
seperti yang diharapkan meskipun sudah mendapatkan laba.

\subsection{Alasan-Alasan}

Melakukan

\section{Merger}

Banyak sekali argument dan alasan yang menyebabkan bank-bank nasional Indonesia melakukan merge diantaranya adalah:pertama pertumbuhan atau diversifikasi yang umumnya dikarenakan untuk mendapatkan pertumbuhan yang cepat. Kedua, sinergi yang diharapkan dapat menghasilkan skala ekonomi untuk mendapatkan pendapatan yang lebih besar. Ketiga, meningkatkan daya pinjam perusahaan. Keempat, ingin menambah keterampilan dan mengembangkan teknologinya. Kelima, dengan merger dan akuisisi diharapkan dapat menutupi kerugian pajak dan dapat meningkatkan pendapatan. Keenam, meningkatkan likuiditas pemilik, karena asumsinya bahwa dengan tergabungnya beberapa perusahaan akan menghasilkan saham yang lebih likuid dari pada perusahan yang terpisah atau kecil dan kemudian untuk melindungi diri dari pengambilalihan akibat hutang perusahaan karena beban hutang ini, kewajiban perusahaan menjadi terlalu tinggi untuk ditanggung oleh bidang perusahaan yang berminat.

\subsection{Proses Atau Tata Cara Merge Pada Bank Nasional}

Proses melakukan merger dan akuisisi pada perusahaan maupun pada perbankan adalah hal yang tidak mudah. Butuh proses yang lama dan cara yang sulit. Adapun tata cara melakukan merger atau adalah pertama Direksi dan komisaris perusahaan wajib membuat surat pernyataan kepada Bapepam dan rapat umum pemegang saham (RUPS). selanjutnya surat pernyataan tersebut harus didukung oleh pihak independen untuk memperoleh persetujuan RUPS perusahaan publik atau emitmen. Kemudian perusahaan wajib menyampaikan pernyataan penggabungan usaha kepada Bapepam yang berisis Rancangan Penggabungan Usaha atau Peleburan Usaha.

Persyaratan yang harus dilengkapi adalah sebagai berikut :

1. Salinan akta pendirian dan perubahan masing-masing perusahaan yang bergabung.

2. Salinan Izin Usaha Tetap bagi perusahaan yang akan meneruskan kegiatan usaha. Jika belum memiliki IUT, perlu dilengkapi dengan BAP (berita pemeriksaan) oleh BKMD setempat. 
3. Risalah RUPS (rapat umum pemegang saham) tentang persetujuan untuk bergabung dari masing-masing perusahaan yang tergabung.

4. Salinan LKPM (laporan keuangan penanaman modal) periode terakhir untuk perusahaan PMA dan PMDN yang akan meneruskan kegiatau usaha.

5. Setelah persyaratan dilengkapi, perusahaan mengisi formulir di kantor BKPM dengan lengkap dan melampirkan permohonan merger. Persetujuan akan dikeluarkan oleh M kepala BKPM dalam bentuk surat persetujuan.

Setelah perusahaan ataupun perbankan tersebut melakukan merger perlu tindak lanjut atas penggabungan usahanya tersebutdan secara bersamasama wajib menyusun kembali RUPS tadi yang sudah disetujui komisaris sebelumnya. Kemudian dibuat beberapa peraturan atas perubahan sifat perusahaan dan diserahkan kepada Bapepam paling lambat akhir hari kerja kedua setelah persetujuan komisaris. Penggabungan suatu perusahaan wajib diumumkan pada masyarakat. Jika
Bapepam tidak mengajukan perubahan dan tambahan informasi terhadap perusahaan merger, maka pengajuan dianggap telah memenuhi syarat.

Kunci sukses strategi merger dapat berjalan dengan baik apabila memenuhi persyaratan sebagai berikut (http://businessenvironment.wordpress.c om) : Dilakukan dengan memanfaatkan keunggulan dan menutupi kekurangan yang dimiliki oleh bank peserta biasanya menyebabkan kegagalan proses merger dan akuisisi. Bank peserta perlu memiliki kemiripan budaya dan falsafah perusahaan yang tidak jauh bertolak belakang. Bank peserta memiliki pimpinan perusahaan yang berdedikasi dan mampu menyelesaikan konflikkonflik secara cepat, bijak dan arif, serta tidak bersifat otoriter. Bank peserta memiliki visi dan misi yang dapat dijalankan oleh bank yang telah digabung. Proses implementasi pasca merger perlu dilakukan dengan melakukan proses harmonisasi produk dan layanan baru, pemantapan dedikasi karyawan dan pembentukan platform dan sistem prosedur yang seragam dan efisien.

\subsection{Dampak Pelaksanaan Merger}

Pelaksanaan merger dan akuisisi baik di Indonesia maupun di negara 
lainnya ternyata membawa dampak positif atau keuntungan nyata bagi perusahaan atau perbankan misalnya seperti lebih cepat untuk memperoleh operasionalisasi perusahaan, teknologi yang digunakan perusahaan lebih bernilai dari pada sebelum melakukan merger, serta mengurangi devisa yang dikeluarkan karena sebagian besar pasar dilayani dengan produk lokal daripada produk impor.

Bukan hanya keuntungan yang dapat kita peroleh dari merger dan akuisisi, ada beberapa kerugian merger dan akuisisi terutama merger lintas batas, antara lain:Perbedaan kultur atau budaya yang disebabkan oleh perpaduan dua organisasi yang berbeda kebiasaaan, nilai, bahkan mungkin negaranya. Kemudian biaya yang disebabkan oleh metode keuangan, serta harga yang dibayarkan mungkin terlalu tinggi akibat berbagai hal yang muncul dalam proses.Kemungkinan reaksi politik dari daerah atau negara tuan rumah, akibat pengambil alihan oleh perusahaan lain. Lalu terkait masalah ketenagakerjaan,dan lain-lain yang menyangkut tenaga kerja.

\subsection{Peraturan Pelaksanaan Merger dan Akuisisi Pada Perbankan}

1. Undang-undang No. 10/1998 tanggal 10 Nopember 1998 tentang Perubahan UU No. 7/1992 tentang Perbankan."WNI, WNA, BdHk Ind, BdHk Asing dapat beli saham Bank Umum secara langsung/melalui bursa efek" (pasal 6)

2. Peraturan Pemerintah No. 28 Tahun 1999 tanggal 7 Mei 1999 tentang Merger, Konsolidasi dan Akuisisi Bank.

3. Peraturan Pemerintah No. 29 Tahun 1999 tanggal 7 Mei 1999 tentang Pembelian Saham Bank Umum.

4. Peraturan Bapepam No. IX.E.1 tentang Benturan Kepentingan Transaksi. Quorum dan Voting dalam RUPS hanya memperhitungkan kehadiran atau suara Pemegang Saham Independen.

5. Peraturan Bapepam No. IX.F.1 tentang Penawaran Tender.

6. Peraturan Bapepam No. IX.G.1 tentang Penggabungan Usaha atau Peleburan Usaha Perusahaan Publik atau Emiten. 
7. Surat Keputusan Direksi Bank Indonesia No. 32/50/KEP/DIR tanggal 14 Mei 1999 tentang Persyaratan dan Tatacara Pembelian Saham Bank Umum.

8. Surat Keputusan Direksi Bank Indonesia No. 32/51/KEP/DIR tanggal 14 Mei 1999 tentang Persyaratan dan Tata Cara Merger, Konsolidasi dan Akuisisi Bank Umum;

9. Surat Keputusan Direksi Bank Indonesia No. 32/52/KEP/DIR tanggal 14 Mei 1999 tentang Persyaratan dan Tata Cara Merger, Konsolidasi dan Akuisisi BPR.

10. Peraturan No. $2 / 27 / \mathrm{PBI} / 2000$ tanggal 15 Desember 2000 tentang Bank Umum.

11. Surat Keputusan Direksi Bank Indonesia No. 32/34/KEP/DIR tanggal 12 Mei 1999 tentang Bank Umum Syariah.

12. Surat Keputusan Direksi Bank Indonesia No. 32/35/KEP/DIR tanggal 12 Mei 1999 tentang BPR.

13. Surat Keputusan Direksi Bank Indonesia No. 32/36/KEP/DIR tanggal 12 Mei 1999 tentang BPR Syariah.

14. Keputusan Direksi Bank Indonesia No. 31/177/KEP/Dir tanggal 31
Desember 1998 juncto Peraturan Bank Indonesia No. 2/15/PBI/2000 tanggal 12 November 1998.

15. Keputusan Direksi Bank Indonesia No. 24/32/Kep/Dir juncto Surat Edaran Bank Indonesia No. 24/1/UKU keduanya tanggal 12 Agustus 1991.

16. Peraturan BI No.5/25/PBI/2003 tentang Penilaian Kemampuan dan Kepatuhan (Kriteria Pemegang Saham, Pengurus Bank dan Pejabat Eksekutif Bank yang tidak lulus Fit and Proper Test).

\section{PENUTUP}

\subsection{Simpulan}

Setelah masa krisis moneter yang dijalani Indonesia serta dampak yang dihadapi oleh beberapa Bank Nasional yang sebagian harus dilikuidasi, muncul strategi alternatif yaitu kebijakan merger sebagai kebijakan dalam mempertahankan bank-bank yang akan dilikuidsi serta memperbaiki kinerja Bank Nasional agar dapat bekerja dan beroperasi secara efisien.

Proses merger bagi perbankan memiliki dampak langsung baik positif maupun dampak negatif seperti yang telah kami paparkan diatas, tergantung dari perspektif kita memandangnya dan 
strategi yang dilakukan oleh perbankan itu sendiri. Keberhasilan upaya merger memerlukan cara yang cukup sulit bagi berbagai pihak yang ingin sukses dalam menerapkan kebijakan ini.

Merger dan akuisisi merupakan strategi yang rumit, karena bukan hanya berkaitan dengan masalah bisnis, tetapi juga terkait masalah hukum dengan perundang-undangannya yang mengatur, masalah perpajakan, akuntansi, perijinan, manajemen, tenaga kerja dan juga kultur usaha dari perusahaan yang melakukan merger dan akuisisi.

Keuntungan utama merger adalah sederhana dan tidak ada biaya yang besar seperti bentuk akuisisi yang lainnya. Alasannya bahwa perusahaan secara sederhana setuju untuk menggabungkan seluruh operasionalnya. Sebagai contoh, disana tidak ada keinginan untuk memindahkan kepemilikan aktiva individu perusahaan yang meleburkan diri ke perusahaan yang utama. Sedangkan kerugian utama adalah bahwa suatu merger harus disetujui dengan suatu hak suara dari pemegang saham tiap-tiap perusahaan. Khususnya, dua pertiga (bahkan lebih) dari hak suara untuk memperoleh persetujuan. Untuk mendapatkan hak suara yang diperlukan akan memakan waktu yang lama dan proses yang tidak mudah.

\subsection{Saran}

Pada dasarnya bank-bank nasional melakukan merger adalah bentuk dari upaya perbaikkan kinerja bank serta menyehatkan kembali bank yang hampir bangkrut. Dilihat dari kasus yang tertera diatas, dampak yang dihasilkan setelah melaksanakan proses merger baik dampak positif maupun dampak negatif.

Meskipun beberapa fakta membuktikan bahwa bank-bank yang melakukan merger mendapatkan keuntungan yang real di segi laba perusahaan tetapi masih terdapat kelemahan dalam penyaluran kredit. Mungkin bukan permasalahan dari strategi merger itu sendiri tetapi permasalahan pada pihak-pihak yang melakukan penggabungan maupun pengambil alihan dalam proses yang kurang efektif.

Merger pada bank nasional bisa berjalan dengan sukses dilihat dari bagaimana bank-bank yang merger tersebut menjalankan dengan proses yang baik dan memanfaatkan keunggulan dan menutupi kekurangan yang dimiliki oleh bank peserta yang biasanya menyebabkan kegagalan proses 
merger dan akuisisi. Seharusnya para bank-bank yang akan melakukan merger melakukan proses harmonisasi produk dan layanan baru, pemantapan dedikasi karyawan, pembentukan platform serta sistem prosedur yang seragam dan efisien guna menghasilkan kinerja yang baik dan sesuai visi dan misi atas dilakukannya penggabungan tersebut.

\section{DAFTAR PUSTAKA}

Boone, Kurtz. Contemporary Business: pengantar bisnis kontemporer. 2007. Jakarta: Salemba Empat.

George Soros, Krisis Kapitalisme Global, (Yogyakarta: Qalam, 2001).

http://businessenvironment.wordpress.co m/2006/11/16/merger-dan akuisisibank-nasional-realitas-dan tantangan/diakses pada tanggal 12/05/2010 pukul 22:13

Hutabarat, Jemsly, Martani Huseini. PFI: Manajemen Strategik Kontemporer (Operasionalisasi Strategi). 2006. Jakarta: Elex Media Kompetindo.

Laporan Kemajuan Pemeriksaan Investigasi atas Kasus Bank Century yang diterbitkan oleh Badan Pemeriksa Keuangan (BPK) yang diserahkan pada Presiden
SBY pada tanggal 23 November 2009.

Sawir, Agnes. Kebijakan pendanaan dan kestrukturisasi perusahaan. 2004. Jakarta: PT Gramedia PU.

Sjahrial, M.M, Dr. Dermawan. Manajemen keuangan lanjutan. 2007. Jakarta: Mitra Wacana Media. 